\title{
The effects of internet of things, strategic green purchasing and green operation on green employee
} behavior: Evidence from hotel industry

\author{
Sautma Ronni Basana ${ }^{a}$, Zeplin Jiwa Husada Tarigan ${ }^{b^{*}}$, Widjojo Suprapto ${ }^{a}$ and Fransisca Andreani ${ }^{a}$
}

${ }^{a}$ Department of Management, Siwalankerto 121-131, Surabaya, Indonesia

${ }^{b}$ Department of Master Management, Siwalankerto 121-131, Surabaya, Indonesia

\section{H R O N I C L E}

\begin{tabular}{l} 
Article history: \\
Received: December 15, 2020 \\
Received in revised format: \\
April 102021 \\
Accepted: April 14, 2021 \\
Available online: \\
April 14, 2021 \\
\hline Keywords: \\
Green employee behavior \\
Green operation \\
Green purchasing \\
Internet of things
\end{tabular}

\section{Introduction}

Environmental changes are getting worse with high air pollution levels and water pollution, so many communities, have promoted sustainable acts to care for the environment. Individuals' ability to build awareness to care for the environment will have a good impact on the environment by reducing the level of current pollution (Alamsyah et al., 2021). The Indonesian Hotel and Restaurant Association of East Java predict the growth of new hotels in East Java will experience a significant decline this year, as much as 3-4 percentages. The development of unique hotels is due to limited land and the proliferation of star-rated hotels of various classes. According to Wijayanto (2019), who reviewed the growth of hotels in East Java, there are around 630-650 members of the Indonesian Hotel and Restaurant Association in East Java, meaning there are also about 650 hotels in East Java. While in Surabaya alone, there are approximately 95 members of PHRI. The amount is considered to be sufficient. Starting from the East side to the West side of Surabaya, now it is full of hotels with various stars. The percentage of new hotel growth in East Java in 2018 is around seven percentages compared to the previous year. In 2018 there were around 10-12 hotels in Surabaya becoming new members of PHRI. These were dominated by 3-star, 4-star and 5-star hotels, but mainly by 3 -star hotels as the rate was not too high. The rapid development of hotels in East Java has a significant impact on the economy. There is some pressure from stakeholders, so hotels have to pay attention to environmental conditions and increase customer demand for environmentally friendly hotels. The hotel industries are recognizing these increasingly critical ecological issues. Hotel industries are now beginning to consider environmental issues as part of the decision-making process,

* Corresponding author. Tel. +62312983145

E-mail address: zeplin@petra.ac.id (Z. J. Tarigan) 
including their operational matters. This trend is turning most hotel industries to be both economically minded and environmentally sustainable.

Nowadays, the focus of the hotel industries is on generating profits through producing goods and services and acting on the preservation of environmental existence. Hotels need to pay attention to external factors to influence efficiency and advance hotel performance (Dapeng et al., 2020). Several hotels in Bandung have begun to implement green concepts by building insightful management of green hotels. Those hotels have started to run environmentally friendly business operations, use efficient electricity, maintain air quality around the hotels, use energy water more efficiently, and create a waste management system (Ferianto et al., 2017). The growth of hotels in East Java requires electrical energy to run all hotel activities and equipment. Hotel energy needs in East Java are mainly from the supply of electricity by the State Electricity Company (Perusahaan Listrik Negara/ PLN). The Central Statistics Agency of East Java Province (2019) stated that electricity consumption in East Java is based on tariffs as per Table 1.

Table 1

Electric Energy Consumption Based on Tariff Group.

\begin{tabular}{lccc} 
& Groups & Amount & Unit \\
\hline Industry & & $13,838,622$ & MWH \\
Household & & $12,967,898$ & MWH \\
Business and Hotel & & $4,118,357$ & MWH \\
Social & & $1,032,286$ & $\mathrm{MWH}$ \\
Buildings & Total & 355,375 & $\mathrm{MWH}$ \\
\hline & & $32,312,538$ & $\mathrm{MWH}$ \\
\hline
\end{tabular}

Based on Table 1, businesses and hotels' electricity consumption in East Java is ranked third at 4,118,357 MWH. The parameters used to measure energy waste are elasticity and energy intensity (Abdou et al., 2020). Energy elasticity is a comparison between growth in energy consumption and economic development. The Republic of Indonesia's Government has begun issuing policies on energy saving or conservation aimed at building lighting, air conditioning, and office equipment that uses electricity (Biantoro \& Permana, 2017). In most hotel industries, electricity consumption is the biggest consumption of energy, so some hotels have implemented the Internet of Things to control lighting and air temperature. The use of the Internet of Things can increase green hotels that the city government has focused on in Surabaya. In recent years, the local government has emphasized that hotel industries must take care of environmental conditions (Merli et al., 2019). Besides, the ASEAN Tourism standardization and certification criteria have set some guidelines for green hotels to follow these requirements: a) Community ownership and management, b) Contribution to social/economic, c) Improvement the environment, d) Interaction between the local community, e) Quality services, f) Quality accommodation, and g) Ensuring performance (Novelli et al., 2016). Green operation includes the procurement of environmentally friendly materials (Jamal et al., 2021). So, the hotel procurement department must apply the criteria for selecting raw materials or materials to choose environmentally friendly products. The hotel procurement department must have standards and easy-to-implement procedures for purchasing materials. The procurement department carries out material purchases to get materials of the specified quality, quantities following hotel needs, and material procurement on time. Green purchasing is essential for hotels to carry out cost efficiency and meet applicable regulations (Khaleeli \& Jawabri, 2021). Hotels determine and assign environmentally friendly materials to meet the needs of hotel operation. Green practices implemented in hotels are carried out by reducing energy use, reducing water use consumption, controlling hotel waste, and reducing hotel waste (Abdou et al., 2020). Furthermore, Chen and Tung's (2014) research states that green hotels can positively impact the employee attitudes of 559 hotel occupants in Taiwan so that many customers are loyal and intend to return to the hotel. Bashir et al. (2019) stated that managers and hotel employees must consider the internal hotel awareness of green hotels and develop practices related to operational implementation. Three hundred and ninety-four (394) surveyed customers stated that personal norms have a significant and positive impact on environmental awareness and behavioral intentions of lodging industries environmentally responsible for their customers, ecological awareness and consumer behavior. Customers who have good knowledge, values, beliefs and personal norms make purchases of products by paying attention to their impact on the environment, then use technology in online shopping to increase green purchasing (Jaini et al., 2020). Product purchasing behavior depends on consumer awareness about the environment; therefore, consumers tend to make green purchasing for friendly products to the environment (Xu et al., 2019; Jamal et al., 2021). Consumer behavior in building environmental awareness is determined by promotions communicated sustainably, so consumers actively carry out and implement green behavior into their everyday life (Alamsyah et al., 2021).

Some previous studies have observed customer behavior in hotel industries. There have been a lot of inputs to be taken into consideration to save the environment. As the number of hotels grows more and more, hotels need to implement green operations, including using toiletries that can be used more than once, clean bedsheets and blankets, and put mineral water using a tumbler (Huang et al., 2014). Hotels are the main thing to consider when travelling and going to a tourist destination. Recently, many customers have demanded that hotels conduct business operations by paying attention to hotel management which cares about green consciousness (Yi et al., 2018). Green hotels have influenced customers as they can provide customer satisfaction. Nowadays, hotel customers are concerned more about the hotel environment's condition (Merli et al., 2019). Many studies were about the implementation of green hotels that could satisfy their customers so that customers were loyal 
and returned to stay at the same hotels again. However, a few studies discuss hotel employees' perceptions in implementing green hotels so that they can provide benefits for hotels as workplaces. This study examines the effect of using the Internet of Things, green purchasing and green operations on green employee behavior.

\section{Literature Review}

The conceptual framework of the research is described further. Conceptual relationships are needed to provide a theoretical and practical picture of the relationship between two or more research variables.

\subsection{Internet of things (IoT) and Green Operation}

Internet of Things (IoT) allows users to manage and optimize electronics and electrical equipment that make use of the internet. Sensors are used in hotels by collecting raw physical data from real-time scenarios and converting them into machine formats that are understandable so that they will be easily exchanged into various forms of data formats (Gardecki et al., 2018). The internet of things is said to be a mechanism of change from an object to a bright object and, in real-time, it can be accessed and captured as needed. It can be perceived as the ability to monitor and control an activity related to resource use (Tan et al., 2020). The resource uses in hotels can be conditioned and controlled automatically by installing radio frequency identification, intelligent sensors, wearable technology, scanners, barcodes, etc. This condition is often used by hotels in the hotel lighting section and room air conditioners. Research conducted by Choi et al. (2015) states that hotel employees have a higher level of satisfaction after the Internet of Things (IoT) being applied or implemented into hotel equipment. IoT based service has been widely used with intelligent tags. Hotel employees can have hotel access or other various security facilities by having facilities to use smart tags. The indicators used to measure IoT are: information technology used by hotels in realtime, information technology related to tourism is readily available, IoT technology is adjustable to hotel room temperature, and IoT technology is adaptable to hotel lighting.

\section{$\mathrm{H}_{1}$ : There is an impact of the Internet of Things (IoT) on Green Operation.}

\subsection{Green Purchasing and Green Operation}

Green Hotel results from management and employee commitment to carry out hotel activities that pay attention to the environment. The front part of the hotel in conducting activities is in the procurement section by purchasing the needed products or environmentally friendly materials (Siagian et al., 2019). Material procurement practices include the use of products made from organic and locally-based or originating from suppliers around the hotel. By prioritizing local products, hotel management has contributed to saving time, reducing fuel consumption, pollution, raising the local economy, and providing healthy products (Sinangjoyo, 2013). Research conducted by Tarigan et al. (2020b) with indicators of measuring green purchasing by reducing waste products and reducing energy use as a resource at hotels has started doing green hotels, which provide efficient services for customers. Procurement can be done by establishing partnerships with local communities. By doing so, hotel management can increase local community awareness of the environment and organize environmentally friendly activities. Green purchasing is measured by purchasing materials that focus on environmentally friendly products, purchasing materials that use low energy, choosing suppliers committed to the environment and buying material products that have a longer life. Meanwhile, to measure green operations in hotels, several indicators are used, such as management setting policies on green hotels, efficient use of energy, efficient water supply and hotel waste management.

\section{$\mathrm{H}_{2}$ : There is an impact of green purchasing on the green operation.}

\subsection{Internet of Things (IoT) and Green Employee Behavior}

Internet of Things can provide an accurate picture of the problems faced by hotel customers related to ignorance and discrepancies faced directly at the hotel location. Hotel employees more easily understand this condition because they get accurate data to establish communication and understand customer desires accurately (Choi et al., 2015). Hotels that apply the concept of environmentally friendly practices will positively impact customer satisfaction to revisit the hotel (Yadav and Pathak, 2017); thus, it forces hotel employees to commit and behave in green manners. To run green hotels, hotels can build green employee behavior. Hotels can be done when employees can apply environmentally friendly insights from their activities and behavior (Khaleeli et al., 2021). Wang's (2012) research states that practical actions related to green employee behavior indicators include: employees can reuse products accordingly, reduce product pollutes, and recycle products. Reduce product uses with fewer products that pollute the environment and switch or use more environmentally friendly products. Recycling is the process of processing waste into new materials or products.

\section{$\mathrm{H}_{3}$ : There is an impact of the Internet of Things on green employee behavior.}

\subsection{Green Purchasing and Green Employee Behavior}

Purchasing environmentally friendly products will provide extra work for hotel employees to meet the policies set by the local government (Jamal et al., 2021). Green product has something to do with consumer value, social value, and green purchasing 
behavior (Khaleeli \& Jawabri, 2021; Alamsyah et al., 2021). The functional importance of a green product may impact different customer behavior as customers have to pay more for the obtained (Wang et al., 2019). Knowledge, attitudes and strong desires of each individual determine customer behavior in consuming green products (Lita et al., 2014). This condition leads to social awareness and social responsibility because customers have understood the consequences of their behavior (Paul et al., 2016). Products that use synthetic materials in cosmetic products in the long term will have an impact on users' health and will harm the environment, therefore consumer behavior in making green purchasing can increase their values and expectations and attention to the green environment (Jaini et al., 2020). Purchasing environmentally friendly products, consumers who already have environmental knowledge and awareness show that they have portrayed their identity that cares for the future environment (Xu et al., 2019). Green purchasing developed by hotels can be implemented if there is attentiveness from top management, establishing policies, and communicating strategic planning with the purchasing department, to build awareness and employee behavior to make companies that care about their environment (Tarigan et al., 2020b). Purchasing activities for consumer goods at hotels need to be considered for their impact on the hotel environment to impact hotel employees in increasing green hotel behavior (Han et al., 2020). Green purchasing applied by the hotels will determine hotel employees to conduct green behavior.

\section{$\mathrm{H}_{4}$ : There is an impact of green purchasing on green employee behavior.}

\subsection{Green Operation and Green Employee Behaviour}

Green operation refers to a hotel's day-to-day activities to serve customers (Khaleeli et al., 2021). These routine activities are the primary responsibility of hotel employees in using environmentally friendly products (Huang et al., 2014). Green operations in hotels by building awareness of the environmental impact employee behavior by carrying out greening activities, especially activities consumed by customers (Han et al., 2020). Many hotels practically implement green hotels. The hotel can be controlled by reducing the use of electrical energy and switching to the use of solar energy, reducing the use of water resources and their utilization, and reducing hotel liquid or solid waste directly as a form of employee responsibility to care for the environment (Abdou et al., 2020). Hotel activities that pay attention to the environment are part of activities to implement green hotels. Green operation activities carried out by hotels include energy efficiency related to electricity savings, energy saving campaigns, energy consumption intensity, energy monitoring, energy-saving implementation through building design; water efficiency by controlling rainwater runoff, water-saving, submeter installation, application of pipeline facility inspection, indoor air quality including smoking-free campaigns, ventilation systems, pollutant sources, CO2 monitoring. All of these activities are the responsibility of hotel management and employees. The elements associated with the hotel include conscious customer awareness of the green hotel environment (Choi et al., 2015).

\section{$\mathrm{H}_{5}:$ There is an impact of the green operation on green employee behavior.}

The conceptual relationship among variables indicates that green purchasing, the internet of things, and green operation improve green employee behavior, so the research model is depicted in Fig. 1.

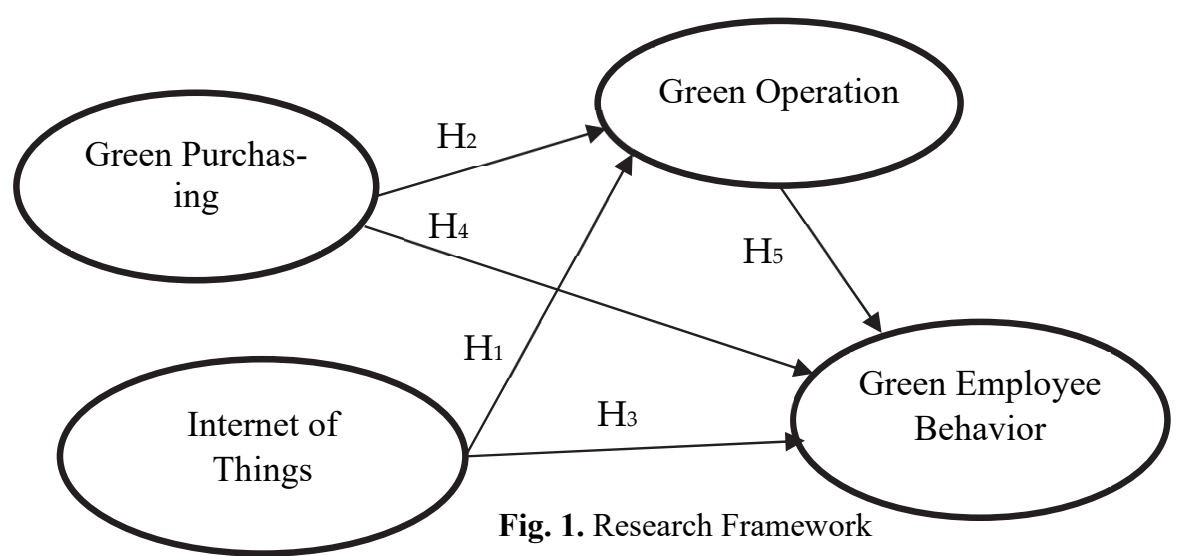

\section{Research methodology}

This study's population is 3-to-5-star hotels located in the East Java region that hold active green hotel certificates. These hotels are listed on traveloka.com and agoda.com and reinforced with East Java culture and tourism publications as many as 265 hotels. Questionnaires were distributed to 82 respondents, and only 65 complete questionnaires were valid for further analysis. Judgmental sampling is used with the provisions that respondents are employees or management staff who understand and know the implementation of green hotels and have worked for more than three years to provide a realistic picture of the green hotel implementation (Ghozali \& Latan, 2015). A five-Likert scale is used with a value of 1 (strongly disagree) 
up to 5 (strongly agree). Each distributed questionnaire consists of some questions like the Internet of Things (4 items), green purchasing (4 items), green employee behavior (3 items), and green hotel operation (4 items) (Tarigan et al., 2020a). Data are analyzed using Structural Equation Modeling Partial Least Square (SEM-PLS) with Java Web Start software tools. The results of data processing are described with descriptive statistical data in Table 2.

Table 2

Statistical Descriptive Data

\begin{tabular}{lc}
\hline \multicolumn{1}{c}{ Variable/Indicators } & Mean \\
\hline Internet of Things (Mean $=4.0270)$ & 4.1692 \\
IT used in real-time about hotels is easy to obtain (IoT1) & 4.0154 \\
IT, especially about travel and tourism is easy to obtain (IoT2) & 3.9231 \\
IoT technology can adjust hotel room temperature (IoT3) & 4.0000 \\
\hline IoT technology can adjust hotel lighting (IoT4) & 4.1692 \\
\hline Green Purchasing (Mean =4.0539) & 4.1077 \\
Purchasing materials focus on environmentally friendly products (GP1) & 4.1231 \\
Purchasing materials that use low energy (GP2) & 3.8154 \\
\hline Choosing suppliers who are committed to the environment (GP3) & 0.6512 \\
Buying product materials that have a longer life (GP4) & 3.9538 \\
\hline Green Operation (Mean = 4.0385) & 4.1077 \\
management sets policy on green hotels (GOH1) & 3.9231 \\
employees use efficient energy (GOH2) & 4.1692 \\
\hline Employees use water supply efficiently (GOH3) & 0.7071 \\
\hline The hotel has waste management (GOH4) & 0.7820 \\
\hline Green Employees Behavior (Mean $=4.2256)$ & 0.7501 \\
\hline employees can carry out reuse materials (GEB1) & 0.7266 \\
\hline employees can reduce materials being used (GEB2) & 0.6944 \\
employees can recycle materials (GEB3) & 0.6875 \\
\hline
\end{tabular}

Table 2 shows that the average value for the Internet of Things variable is 4.0270. The hotels' Internet of Things has run well, with the lowest value is IoT3 (3.9231), and the highest value is IoT1 indicator (4.1692). The internet of things has been used implicitly by hotels to efficiently use their resources, such as in controlling hotel room temperature, especially in large meeting rooms, halls, and hotel rooms. Automatic systems can also carry out controlling lights, so it does not require employees to turn on and off the device. The green purchasing variable has a mean value of 4.0539; this shows green purchasing has been done well in the hotels with the lowest value in GP4 (3.8154) and the highest value in GP1 (4.1692). This condition illustrates that many hotels have programs related to the implementation of green hotels, especially in controlling the procurement of products that are friendly to use and environmentally friendly. The hotel procures materials, including changes to the use of bottled drinking water, replacing it with centralized mineral water provision by providing a teapot to each hotel room so that consumers can take mineral water as needed. Paper-based wrappers replace plastic wrappers for toiletries, so they are recyclable. The procurement of environmentally friendly materials in hotels depends on the green purchasing program. Table 2 also shows that the average mean value of green hotel operation is 4.0385. It shows that employees have run green hotel operations well, with the lowest value in GO3 of 3.9231 and the highest value in GO4 of 4.1692. Green operations have been implemented in hotels, including replacing shampoo and soap in plastic tubes placed in each hotel bathroom into the provision of shampoo, soap, and body lotion in larger containers pinned to the bathroom wall to avoid thrashing many plastic tubes. The standard operating procedure for replacing immediately used towels in bathrooms by hotel employees for laundry has been changed by educating customers to care about the environment and by introducing them through hotel brochures that green hotels have been running by replacing towels if necessarily requested. Finally, green employee behavior has an average mean value of 4.2256 with the lowest value of GEB3 (4.1077) and the highest value of GEB2 (4.2923). It shows that employees have been able to implement green practices very well in East Java star hotels.

\section{Data Analysis}

The suitability of the PLS model needs to be done to meet the specified requirements by conducting an outer model test. A validity test measures the accuracy and feasibility of the instruments used and the extent to which the instruments can perform functionally (Ghozali \& Latan, 2015). The validity test is good if the convergent validity value obtained from the cross-loading value is above 0.50 (Hair et al., 2019). The results of the analysis can be seen in Table 3. Table 3 shows that the Internet of Things with the lowest cross-loading is found on IoT2 of 0.625 ; the lowest cross-loading of green operation is GOH2 of 0.728 ; the lowest green purchasing cross-loading is GP1 of 0.718, and the lowest cross-loading of green employee behavior is GEB1 of 0.647. So, all indicators have fulfilled the requirements and are said to be valid. Furthermore, a validity test is used to measure whether the measurement is error-free and rely on future research (Ghozali \& Latan, 2015; Sekaran \& Bougie, 2019). Variables are said to have good reliability when the composite reliability value is above 0.70 (Hair et al., 2019). Based on Table 4 , the Internet of Things has a reliability composite of 0.836 ; green operation of 0.842 ; green purchasing of 0.859 and green employee behavior of 0.800 . Thus, all variables have met the specified composite reliability requirement, that is, above 0.70 . 
Table 3

The results of convergent validity with cross-loading

\begin{tabular}{|c|c|c|c|c|}
\hline Indicators & Internet of Things (IoT) & $\begin{array}{c}\text { Green Operation Hotel } \\
\text { (GOH) }\end{array}$ & Green Purchasing (GP) & $\begin{array}{c}\text { Green Employee Behavior } \\
\text { (GEB) }\end{array}$ \\
\hline IoT1 & 0.766 & 0.263 & 0.257 & 0.063 \\
\hline IoT2 & 0.625 & 0.023 & 0.230 & 0.088 \\
\hline IoT3 & 0.739 & 0.030 & 0.122 & 0.223 \\
\hline IoT4 & 0.856 & 0.340 & 0.368 & 0.384 \\
\hline GOH1 & 0.089 & 0.774 & 0.458 & 0.143 \\
\hline $\mathrm{GOH} 2$ & 0.242 & 0.728 & 0.386 & 0.058 \\
\hline GOH3 & 0.190 & 0.738 & 0.354 & 0.257 \\
\hline $\mathrm{GOH} 4$ & 0.345 & 0.783 & 0.423 & 0.172 \\
\hline GP1 & 0.135 & 0.411 & 0.718 & 0.390 \\
\hline GP2 & 0.429 & 0.578 & 0.774 & 0.205 \\
\hline GP3 & 0.490 & 0.569 & 0.809 & 0.388 \\
\hline GP4 & 0.369 & 0.499 & 0.806 & 0.380 \\
\hline GEB1 & 0.032 & 0.087 & 0.207 & 0.647 \\
\hline GEB2 & 0.296 & 0.264 & 0.330 & 0.857 \\
\hline GEB3 & 0.347 & 0.082 & 0.284 & 0.755 \\
\hline
\end{tabular}

Table 4

The Results of Composite Reliability

\begin{tabular}{lcc} 
& Variables & Composite Reliability \\
\hline Internet of Things & 0.836 \\
Green Operation & 0.842 \\
Green Purchasing & 0.859 \\
Green Employee Behavior & 0.800 \\
\hline
\end{tabular}

Based on the data processing with PLS, the model results can be observed in Fig. 2.

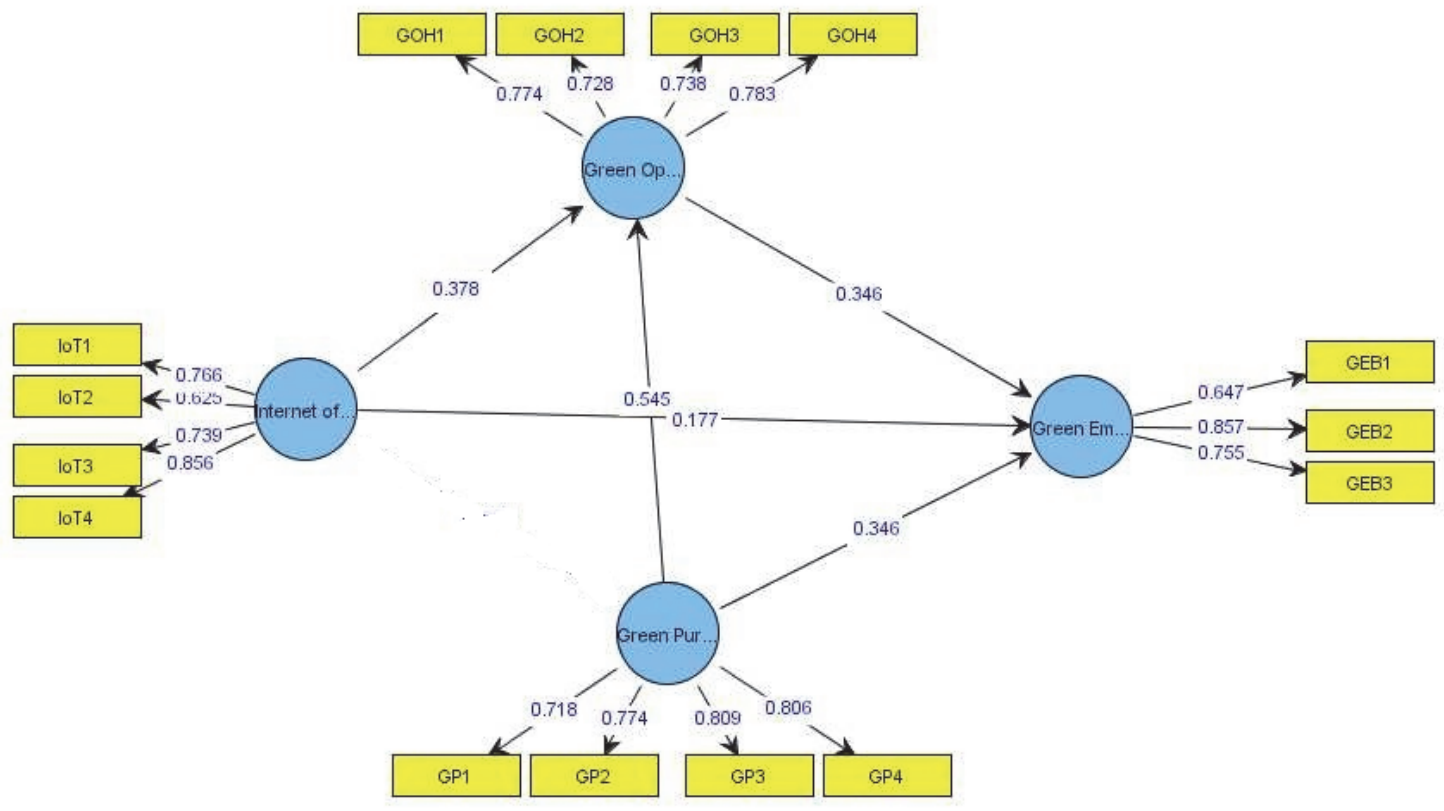

Fig. 2. Results of the research model processing with PLS

The more Internet of Things is used in star hotels in East Java, the more the star hotels can control hotel lighting (I0T4) and adjust room temperature (IoT3). By doing so, hotels can implement green operation as it saves more energy.

Table 5

Inner Model Tests for Direct Effect Assessment

\begin{tabular}{lcc}
\hline \multicolumn{1}{c}{ Path Construction } & Original Sample Estimate & Standard Deviation \\
\hline Internet of Things $\rightarrow$ Green Operation & 0.378 & 0.123 \\
Green Purchasing $\rightarrow$ Green Operation & 0.545 & 0.123 \\
Internet of Things $\rightarrow$ Green Employee Behavior & 0.177 & 0.152 \\
Green Purchasing $\rightarrow$ Green Employee Behavior & 0.346 & 4.415 \\
Green operation $\rightarrow$ Green Employee Behavior & 0.346 & 1.160 \\
\hline
\end{tabular}


Thus, the first hypothesis is supported. Moreover, green purchasing impacts green operation as much as 0.545 with the tstatistic value of 4.415 that is above the t-count of 1.960 . Green purchasing impacts green operation due to the hotels' procurement department's ability to select suppliers committed to the environment (GP3) and buy product materials with a longer life or more extended service life (GP4). Thereby, green operation can be done well. It also shows that employees' needs to run green operational hotels have been met, and hotels can buy environmentally friendly materials. Thus, the second hypothesis is also supported. Furthermore, the direct assessment of Internet of Things to green employee behavior is 0.177 with the value of t-statistic 1.160, which is below its t-count 1.960. So, the Internet of Things has not had an impact on green employee behavior significantly. The third hypothesis is not supported. This is due to the fact that Internet of Things' usage can help hotels operate their business activities automatically. The Internet of Things enables hotels to adjust their lighting and room temperature accordingly by using sensors. Thus, it doesn't influence green employee behavior; but it must go through green operation as an intervening variable. Moreover, the data analysis results for testing the research hypotheses are shown with the inner model test, which is presented in Table 5.

Based on Table 5, it is found that the Internet of Things has an impact on green operation as much as 0.378 significantly because its t-statistic value of 3.069 is above the t-count of 1.960. Furthermore, the direct assessment because Things of green employee behavior is 0.177 , with the value of t-statistic 1.160 , which is below its t-count of 1.960 . So, the Internet of Things has not had an impact on green employee behavior significantly. The third hypothesis is not supported. This is because Internet of Things' usage can help hotels operate their business activities automatically. The Internet of Things enables hotels to adjust their lighting and room temperature accordingly by using sensors. Thus, it doesn't influence green employee behavior; but it must go through green operation as an intervening variable. Besides, green purchasing impacts green employee behavior as much as 0.346 with a t-statistic of 2.523 , which is above the t-count of 1.960 . Therefore, the fourth hypothesis is supported. Green purchasing can influence green employee behavior significantly. Hotels can buy or procure product materials that are environmentally friendly from their suppliers. So, it enables employees to implement green activities by reusing product materials to be more efficient as it can reduce the use of product materials. The hotel procurement department can find committed suppliers that can provide environmentally friendly materials, and then, hotels coordinate and collaborate with their employees to make use of the materials optimally. Finally, green operation impacts green employee behavior as much as 0.347 with a t-statistic of 2.639 that is above t-count value of 1.960 . Thus, green operation can influence green employee behavior significantly. So, the last hypothesis is supported. Hotel employees can do business activities in friendly ways. They can use energy efficiently (reduce materials). They can also reuse materials accordingly and recycle the materials when needed to add hotel value for their customers and environment.

\section{Discussion}

Based on the descriptions in Figure 2 and Table 5, it is found that the first hypothesis is accepted, so it can be said that the internet of things has a significant effect on green operations. The hotel's ability to implement the internet of things in monitoring and controlling the temperature of large rooms, hotel rooms automatically and the lighting at the hotel location can also provide efficiency in the use of hotel resources. The implementation of the internet of things can reduce excessive wastes generated by hotels, so hotel management makes policies regarding changes to standard operating procedures and builds employee and consumer awareness while in the hotel about caring for the environment through brochures placed in every room that are easy to read and easy to understand. This study confirms the research results, which state that the internet of things has a significant effect on green operations (Gardecki et al., 2018; Tan et al., 2020; Choi et al., 2015).

The second hypothesis is accepted that green purchasing has an impact on increasing green operations. The theory accepted is determined by the existence of a policy on material procurement in hotels by building collaboration with suppliers so that they are committed to providing products from environmentally friendly materials and have a relatively long service life and can be recycled. Controls exercised by green purchasing will provide better green hotel operations due to efficiency in resource use. This study confirms the research results, which state that green purchasing has an impact on increasing green operations (Siagian et al., 2019; Sinangjoyo, 2013; Tarigan et al., 2020b).

The third hypothesis is accepted, so the internet of things can increase green employee behavior. The company uses automatic controls and monitors in regulating air conditioning in each room and lighting throughout the hotel premises by giving awareness, pride, and knowledge to hotel employees. Employees have implemented green operation practices regularly by using materials according to predetermined needs and carrying out "reduce, reuse, recycle" these materials. This study confirms the research results, which state that internet of things can increase green employee behavior (Choi et al., 2015; Yadav and Pathak, 2017; Khaleeli et al., 2021; Wang, 2012).

The fourth hypothesis is accepted, that green purchasing has an impact on increasing green employee behavior. It means the purchase of environmentally friendly materials determined by the hotel and growing commitment from suppliers' impact on employee knowledge in using these materials to be more efficient. Employees can also use these materials repeatedly as needed and can make improvements to the materials or seek other uses. This study confirms the research results, which state that green purchasing has an impact on increasing green employee behavior (Khaleeli \& Jawabri, 2021; Alamsyah et al., 2021; Wang et al., 2019; Lita et al., 2014; Paul et al., 2016; Jaini et al., 2020; Han et al., 2020). 
The fifth hypothesis is accepted, so green operation affects green employee behavior. This condition illustrates that the green operation is determined by management through policies and focuses on reducing waste to build employee awareness and knowledge in using all hotel equipment and hotel materials efficiently. Hotel employees also make innovations in utilizing waste as needed, for example, the water that comes out of each hotel bathroom is stored and treated in a large container for reusing water plants around hotel locations, food scraps from the hotel kitchen are treated and handed over to the community for animal food. The hotel's plant wastes are placed in a specific location and buried in the soil, which can be used as a natural fertilizer. This study confirms the research results, which state that green operation affects green employee behavior (Khaleeli et al., 2021; Huang et al., 2014; Han et al., 2020; Abdou et al., 2020; Choi et al., 2015). This study has some limitations in observing the internet of things, hotel operations, and green purchasing in building green employee behavior, so it is necessary to develop how the hotel industry impacts, especially on the hotel innovation process, hotel performance improvement, and green economics.

\section{Conclusions}

Green hotel is a new provision and policy held by the East Java local government for hotels to carry out their business activities. Hotels have to comply with these regulations to stay competitive and sustainable. From the results of this research, first, it is known that the Internet of Things (IoT) has a significant and positive impact on green hotel operation. Second, green purchasing can increase green operational hotels because of the efficient partnership with hotel suppliers to procure environmentally friendly product materials. Third, the Internet of Things (IoT) does not significantly impact green employee behavior; while green purchasing can have a significant impact on green employee behavior. Then, green purchasing set by the hotels turns out to be able to provide durable and environmentally friendly materials. Therefore, employees can use the materials optimally. Finally, it is found that hotel green operation impacts energy usage and waste management efficiently. Thus, it enables hotel employees to reduce, reuse and recycle product materials that provide value-added for the hotels.

\section{References}

Abdou, A.H., Hassan, T.H., \& Dief, M.M.E. (2020). A description of Green Hotel Practices and Their Role in Achieving Sustainable Development. Sustainability, 12(22), 9624. doi:10.3390/su12229624

Alamsyah, D.P., Othman, N.A., Bakri, M.H., Udjaja, Y., \& Aryanto, R. (2021). Green awareness through environmental knowledge and perceived quality. Management Science Letters 11(1), 271-280, DOI: 10.5267/j.msl.2020.8.006

Bashir, S., Khwaja, M. G., Turi, J. A., \& Toheed, H. (2019). Extension of planned behavioral theory to consumer behaviors in green hotel. Heliyon, 5, e02974. doi.org/10.1016/j.heliyon.2019.e0297

Biantoro, A. W., \& Permana, D. S. (2017). Energy audit analysis to achieve energy efficiency in AB Building, District Tangerang Banten. Jurnal Teknik Mesin, 6, 85-93.

Chen, M., \& Thung, P. (2014). Developing an extended Theory of Planned Behavior model to predict consumers' intention to visit green hotels. International Journal of Hospitality Management, 36, 221-230. doi.org/10.1016/j.ijhm.2013.09.006

Choi, H., Jang, J., \& Kandampully, J. (2015). Application of the extended VBN theory to understand consumers' decisions about green hotels. International Journal of Hospitality Management, 51, 87-95. doi.org/10.1016/j.ijhm.2015.08.004

Dapeng, Z., Jinghua, T., Lingxu, Z., \& Zhiyuan, Y. (2020). Higher tourism specialization, better hotel industry efficiency. International Journal of Hospitality Management, 87, 02509, doi.org/10.1016/j.ijhm.2020.102509

Ferianto, A.R.D., Darsiharjo, \& Marhanah, S. (2017). Green hotel concept influence to bandung tourists visit interest. Antologi Manajemen Resort \& Leisure, 2(2), 1-9. http://repository.upi.edu/13624/10/S_MRL_1005612_Appendix.pdf

Gardecki, A., Podpora, M., \& Kawala-Janik, A. (2018). Innovative internet of things-reinforced human recognition for human-machine interaction purposes. IFAC-PapersOnLine, 51(6), 138-143. doi.org/10.1016/j.ifacol.2018.07.143

Ghozali, I., \& Latan, H. (2015). Concepts, Techniques, Applications Using Smart PLS 3.0 for Empirical Research. BP UNDIP, Semarang.

Hair, J.F., Risher, J.J., Sarstedt, M., \& Ringle, C.M. (2019). When to use and how to report the results of PLS-SEM. European Business Review, 31(1), 2-24. https://doi.org/10.1108/EBR-11-2018-0203

Han, H., Chen, C., Lho, L.H., Kim, H., \& Yu, J. (2020). Green Hotels: Exploring the Drivers of Customer Approach Behaviors for Green Consumption. Sustainability, 12(21), 9144, 1-14. doi:10.3390/su12219144

Huang, H.C., Lin, T.H., Lai, M.C., \& Lin, T.L. (2014). Environmental consciousness and green customer behavior: An examination of motivation crowding effect. International Journal of Hospitality Management, 40, $139-149$. doi.org/10.1016/j.ijhm.2014.04.006

Jaini, A., Quoquab, F., Mohammad, J., \& Hussin, N. (2020). Antecedents of green purchase behavior of cosmetics products: An empirical investigation among Malaysian consumers. International Journal of Ethics and Systems, 36(2), $185-203$. DOI 10.1108/IJOES-11-2018-0170

Jamal, F.N., Othman, N.A., Saleh, R.C., \& Chairunnisa, S. (2021). Green purchase intention: The power of success in green marketing promotion. Management Science Letters, 11(5), 1607-1620, DOI: 10.5267/j.ms1.2020.12.011

Khaleeli, M., \& Jawabri, A. (2021). The effect of environmental awareness on consumers' attitudes and consumers' intention to purchase environmentally friendly products: Evidence from United Arab Emirates. Management Science Letters, 11(2), 555-560, DOI: $10.5267 /$ j.msl.2020.9.011 
Khaleeli, M., Oswala, N., \& Sleema, H. (2021). The moderating effect of price consciousness on the relationship between green products purchase intention and customers' purchase behavior: Does environmental knowledge matters? Management Science Letters, 11(5), 1651-1658, DOI: 10.5267/j.msl.2020.12.007

Lita, R. P., Surya, S., Ma'ruf, M., \& Syahrul, L. (2014). Green attitude and behavior of local tourists towards hotels and restaurants in west Sumatra, Indonesia. Procedia Environmental Sciences, 20, 261- 270. doi.org/10.1016/j.proenv.2014.03.033.

Merli, R., Preziosi, M., Acampora, A., \& Ali, F. (2019). Why should hotels go green? Insights from guests experience in green hotels. International Journal of Hospitality Management, 81, 169-179. doi.org/10.1016/j.ijhm.2019.04.022

Novelli, M., Klatte, N., \& Dolezal, C. (2016). The ASEAN community-based tourism standard: looking beyond certification. Tourism Planning \& Development, 14(2), 260-281.

Paul, J., Modi, A., \& Patel, J. (2016). Predicting green product consumption using the theory of planned behavior and reasoned action. Journal of Retailing Consumer Services, 29, 123-134. doi.org/10.1016/j.jretconser.2015.11.006

Sekaran, U., \& Bougie, R. (2019). Research Methods for Business (6 ${ }^{\text {th }}$ Ed.). Jakarta: Salemba Empat.

Siagian, H., Tarigan, Z. J. H., \& Andreani, F. (2019). The influence of information integration on hotel performance through the green operation and strategic purchasing. WCSE Summer 2019, 26-31. http://www.wcse.org/WCSE_2019_SUMMER/W05.pdf

Sinangjoyo, N. J. (2013). Green hotel as a competitiveness of a destination (Case study the star hotel industry in Yogyakarta). Jurnal Nasional Pariwisata, 5(2), 83-93.

Tan, B.Q., Wang, F., Liu, J., Kang, K., \& Costa, F. A. (2020). Blockchain-Based Framework for Green Logistics in Supply Chains. Sustainability, 12(10), 1-23, 4656. doi:10.3390/su12114656

Tarigan, Z.J.H., Basuki, R., \& Siagian, H. (2020a). The impact of information technology quality on electronic customer satisfaction in the movie industry. International Journal of Data and Network Science, 4(3), 263-270, DOI: $10.5267 /$ j.ijdns.2020.8.001

Tarigan, Z.J.H., Tanuwijaya, N.C., \& Siagian, H. (2020b). Does top management attentiveness affect green performance through green purchasing and supplier collaboration? Academy of Strategic Management Journal, 19(4), 1-10, 1939-610419-4-590.

The Central Statistics Agency of East Java Province. (2019). Electric Energy Consumption According to Branch and Tariff Group Offices. Retrieved December 11, 2019 https://jatim.bps.go.id/statictable/2017/10/16/660/konsumsi-energi-listrikmenurut-kantor-cabang-dan-golongan-tarip-di-provinsi-jawa-timur-mwh-2016.html

Wang, R. (2012). The investigation of green best practices for hotels in Taiwan. Procedia - Social and Behavioral Sciences, 57, 140 - 145. doi.org/10.1016/j.sbspro.2012.09.1167

Wang, Y., Li, Y., Zhang, J., \& Su, X. (2019). How impacting factors affect Chinese green purchasing behavior based on fuzzy cognitive maps. Journal of Cleaner Production, 240, 118199. doi.org/10.1016/j.jclepro.2019.118199

Wijayanto. (2019). The growth of new hotels in East Java is predicted to reduce by 3-4 percent. Retrieved January 20, 2020 , from https://radarsurabaya.jawapos.com/ read/2019/02/08/118460/pertumbuhan-hotel-baru-di-jatim-diprediksi-turun-34-persen.

Xu, L., Prybutok, V., \& Blankson, C. (2019). An environmental awareness purchasing intention model. Industrial Management \& Data Systems, 119(2), 367-381, doi.org/10.1108/IMDS-12-2017-0591

Yadav, R., \& Pathak, G. S. (2017). Determinants of consumers' green purchase behavior in a developing nation: applying and extending the theory of planned behaviour. International Journal of Hospitality Management, 134, 114-122. DOI: 10.1016/j.ecolecon.2016.12.019

Yi, S., Li, X., \& Jai, T. M. (2018). Hotel guests' perception of best green practices: A content analysis of online reviews. Tourism Hospitality Research, 18(2), 191-202, doi.org/10.1177/1467358416637251 
(C) 2021 by the authors; licensee Growing Science, Canada. This is an open access article distributed under the terms and conditions of the Creative Commons Attribution (CC-BY) license (http://creativecommons.org/licenses/by/4.0/). 